\title{
Participation of Religious Leaders in Helping the Success of the Government's Covid-19 Vaccination Program
}

\author{
Simon $^{1 *}$, Alfons Renaldo Tampenawas ${ }^{2}$, Joko Santoso ${ }^{3}$, Astrid Maryam Yvonny Nainupu ${ }^{4}$, \\ Semuel Ruddy Angkouw ${ }^{5}$, Alvonce Poluan ${ }^{6}$ \\ ${ }^{1} \&{ }^{6}$ Sekolah Tinggi Teologi Anugrah Indonesia, Jawa Timur, Indonesia \\ ${ }^{2}$ Sekolah Tinggi Teologi Yerusalem Baru Manado, Sulawesi Utara, Indonesia \\ ${ }^{3}$ Sekolah Tinggi Theologia Nazarene Indonesia, Yogyayarta, Indonesia \\ ${ }^{4}$ Sekolah Tinggi Teologi Simpson Ungaran, Jawa Tengah, Indonesia \\ ${ }^{5}$ Sekolah Tinggi Alkitab Batu, Jawa Timur, Indonesia \\ email: *simonpetrus45144@gmail.com
}

\begin{abstract}
The basic idea of this paper departs from observations in the virtual and realworld, where certain people or groups are found who disagree with the need to be vaccinated. If the country's people reject the mandatory mass vaccination, which the government is discussing, it will take a long time to restore normal activities. This paper uses a descriptive qualitative method with a literature study approach. The description in this paper found some people's rejection of vaccines because their views or perceptions about Covid-19 influenced it. The government's hope to immediately carry out mass vaccinations for all Indonesian people must be balanced with maximum efforts to make it happen. This substantial effort can be made by providing massive education in the media, conducting public campaigns, and providing guarantees to vaccine recipients. On the other hand, the success of this vaccination program does not only depend on the government; all elements of society are expected to contribute in this regard, especially religious leaders. The manifestation of the involvement of religious leaders is by educating the congregation through the pulpit about vaccines. In addition, religious leaders must also set an example by participating in vaccinations and actively countering hoax news. The dominance of factual information about vaccines dominates mass lines on social media.
\end{abstract}

Key Words: Religious Leaders, Vaccines, Covid-19, Government

\begin{abstract}
ABSTRAK: Ide dasar tulisan ini berangkat dari pengamatan di dunia maya dan nyata, yang mana ditemukan orang-orang atau kelompok tertentu yang tidak menyetujui keharusan untuk divaksin. Apabila masyarakat tanah air kecenderungan menolak wajib vaksinasi massal yang diwacanakan oleh pemerintah, tentu akan lama memulihkan aktivitas normal kembali. Tulisan ini menggunakan metode kualitatif deskriptif dengan pendekatan studi literatur. Uraian pada tulisan ini ditemukan, penolakan sebagian orang terhadap vaksin karena dipengaruhi oleh pandangan atau persepsi mereka mengenai Covid-19. Harapan pemerintah untuk segera melakukan vaksinasi massal ke seluruh masyarakat tanah air, harus diimbangi upaya yang maksimal dalam mewujudkannya. Upaya konkret itu dapat dilakukan dengan pemberian edukasi secara masif dimedia, melakukan kampanye publik dan adanya jaminan kepada penerima vaksin. Disisi lain suksesnya program vaksinasi ini tidak hanya bergantung kepada pemerintah, semua elemen masyarakat diharapkan kontribusinya dalam hal ini terutama para pemuka agama. Wujud dari keterlibatan pemuka agama adalah dengan mengedukasi jemaat melalui mimbar tentang vaksin. Selain itu, pemuka agama juga harus memberi contoh dengan ikut divaksin, serta aktif mengcounter berita hoax agar dominasi berita faktual tentang vaksin menguasai lini massa di media sosial.
\end{abstract}

Kata Kunci: Pemuka Agama, Vaksin, Covid-19, Pemerintah

Article History: Submitted: 4 Mei 2021

Revised: 21 Juli 2021

Published: 29 Juli 2021 


\section{PENDAHULUAN}

Covid-19 telah satu tahun lebih melanda dunia, tetapi tanda-tanda Covid-19 akan mereda tampaknya belum menemukan titik kepastiannya. Covid19 seakan telah membuat siapa saja kehilangan kebebasannya dalam melakukan rutinitas tanpa harus mengenakan pelindung diri (Meri, Khusnul, Suhartati, Mardiana, \& Nurpalah, 2020, pp. 26-33). Pramana et al. (2021) mengemukakan virus Covid-19 mempengaruhi seluruh penduduk di Indonesia saat ini. Virus Covid-19 telah mempengaruhi berbagai bidang seperti sosial, ekonomi, pariwisata, dan pendidikan (Pramana et al., 2021). Mayoritas orang menghendaki kembalinya kehidupan normal sebelum Covid-19 berkecamuk di berbagai negara. Sejak merebaknya Covid19, sebagian negara-negara menerapkan lockdown sebagai upaya memproteksi warganya agar seminim mungkin terpapar Covid-19. Alfano dan Ercolano (2020, p. 510) mengemukakan penerapan lockdown telah mendorong negara dan masyarakat ke jurang perdebatan, apakah perlu membuat kebijakan ini. Melakukan lockdown akan membuat banyaknya kegiatan terhenti, ekonomi menurun serta tingkat produktivitas masyarakat terjun bebas. Negara yang menerapkan kebijakan lockdown adalah Tiongkok karena kasus pertama Covid-19 ditemukan di Wuhan. Dengan demikian jika sebuah negara hendak menerapkan lockdown jangan berpatokan kepada kesuksesan Tiongkok (Alfano \& Ercolano, 2020, p. 510).

Di tengah kejenuhan masyarakat dunia karena kondisi Covid-19 yang belum mereda, muncul secercah sinar harapan melalui vaksin. Hadirnya vaksin untuk mengatasi pandemi ini membawa semua orang kembali bersikap optimis, bahwa menjalani kehidupan normal akan kembali tiba tanpa mengenakan atribut-atribut pelindung diri. Vaksin diyakini akan membawa setiap negara untuk kembali normal. Harapan ini tentu didasarkan pada vaksin yang dipercayai paling efektif dan ekonomis untuk mencegah penyakit menular terutama Covid-19. Karena itulah pengembangan terhadap vaksin sejauh ini telah dilakukan oleh 40 perusahaan farmasi dan lembaga akademis di seluruh dunia dengan tujuan melawan virus corona
(Makmun \& Hazhiyah, 2020, p. 52). Dengan pengembangan vaksin yang dilakukan diharapkan memiliki tingkat efektivitas yang tinggi, dan berman-faat bila sudah diterapkan karena dapat mencegah pandemi secara berulang-ulang atau terus-menerus (Graham, 2020, p. 945).

Tersedianya vaksin Covid-19 di Indonesia tentu masyarakat tanah air mengharapkan gerak cepat pemerintah untuk pemenuhan vaksin bagi warga. Pemenuhan vaksin Covid-19 sudah seharusnya menjadi tanggung jawab penuh pemerintah sebagai bentuk kepedulian Negara yang tertuang dalam Pembukaan UUD NRI tahun 1945 yang menyatakan untuk melindungi segenap rakyat dan seluruh tumpah darah Indonesia, memajukan kesejahteraan umum, mencerdaskan kehidupan bangsa, dan ikut melaksanakan ketertiban dunia yang berdasarkan kemerdekaan, perdamaian abadi dan keadilan sosial (Masnun, Sulistyowati, \& Ronaboyd, 2021, p. 43). Dengan negara bertanggung jawab pada penyediaan vaksin kepada masyarakat, pemerintah telah mengimplementasikan dan mewujudnyatakan isi undang-undang Dasar 1945 tentang tanggung jawab negara untuk menjaga kesehatan masyarakatnya (Isriawaty \& others, 2015).

Langkah pemerintah untuk sesegera mungkin memberikan vaksin kepada semua masyarakat agar kembali normal sebagaimana dahulu, ternyata juga menimbulkan gejolak di masyarakat jika diamati dari berita - berita yang beredar di dunia maya. Gejolak penolakan akan vaksin mulai muncul karena suarasuara sumbang yang mempertanyakan apakah vaksin tersebut halal atau tidak beresiko ketika disuntikkan ke tubuh (Satu, 2020). Untuk mensukseskan program vaksin karena adanya kenyataan penolakan yang massif dari masyarakat maka pemerintah mengeluarkan perpres no 14 tahun 2021 tentang perubahan peraturan Presiden no 99 tahun 2020 yang isinya adalah pemberian sanksi administratif bahkan ancaman hukuman pidana bagi masyarakat yang menolak di vaksin karena dianggap menghalangi penanggulangan penyebaran covid (Jeannifer, 2021). Sementara Dwipayana mengemukakan adanya penolakan terhadap vaksin pengaruh dari sikap anti saintisme, 
konservatisme agama serta sistem demokrasi yang dibangun dengan berjubahkan keagamaan (Dwipayana, 2020, p. 331). Penolakan terhadap vaksin karena mengedepankan agama sebagai tolak ukur dalam menilai semuanya.

Masifnya gerakan penolakan vaksin di dunia maya tak lepas dari merajalelanya berita hoax di media sosial. Berita hoax tentang Covid-19 telah menyebabkan masyarakat menjadi sulit untuk membedakan mana berita yang bersifat nyata dan rekayasa. Akibat dari banyaknya berita hoax itu memunculkan aksi penolakan vaksin yang dilakukan sebagian orang (Sari, 2021). Ini pula yang dikemukakan oleh Shahsavari et al. (2020) dalam penelitiannya, ketika awal mula Covid-19 melanda Amerika, banyak warganya menyimpulkan bahwa pandemi ini hanya merupakan tipuan dan kebohongan. Akibatnya, warga bersikap masa bodoh, serta tidak memakai masker apalagi social distancing. Ini disebabkan karena banyaknya berita di media yang bersifat anonim, hoax, dan konspirasi (Shahsavari et al., 2020). Pendapat senada dikemukakan oleh Imhoff dan Lamberty selama pandemi ini berlangsung, berbagai organisasi dan pemerintahan dunia mengambil tindakan yang ekstra dengan mengedukasi masyarakat global yang bertujuan mengurangi laju penularan Covid-19. Namun disaat yang sama, berita pandemi ini telah memunculkan spekulasi dan teori konspirasi dengan mengabaikan ilmu pengetahuan, maupun medis (Imhoff \& Lamberty, 2020).

Bila semakin banyak masyarakat tanah air menolak vaksinasi tentu akan mengakibatkan pemerintah kesulitan memulihkan keadaan ekonomi, sosial maupun keagamaan. Apabila kondisi seperti ini berkelanjutan secara terus-menerus, tentu berpotensi menyebabkan runtuhnya negara dan berbahaya bagi tatanan sosial di masyarakat. Oleh sebab itu, untuk mensukseskan vaksinasi massal agarantusiasme masyarakat tinggi, maka keterlibatan pemuka agama sebagai komunikator dan mediator umat beragama diperlukan. Tulisan ini akan menguraikan bagaimana keterlibatan pemuka agama dalam membantu program vaksinasi pemerintah? Pemuka agama yang dimaksud dalam tulisan ini secara spesifik adalah pemuka agama Kristen yang menggembalakan jemaat. Sebelumnya Aula (2020) telah membahas tulisan tentang Peran Tokoh Agama dalam memutus rantai pandemi. Dalam temuannya ia mengemukakan bahwa tokoh agama berperan dalam memutus rantai penyebaran Covid-19 karena ia dapat meredam kekalutan umat dan menjadi corong informasi melalui perannya sebagai komunikator. Ada juga tulisan dari Muchammadun et al. (2021) tentang peran tokoh agama dalam menangani penyebaran Covid-19. Temuan terhadap penelitiannya tokoh agama bisa berperan sebagai agen sosial dalam pencegahan Covid-19 melalui kegiatan keagamaan yang dilakukannya.

Letak kebaruan yang membedakan tulisan ini adalah karena tulisan ini menguraikan keterlibatan pemuka agama Kristen secara nyata di tengah-tengah kehidupan berjemaat di gereja dalam membantu program vaksinasi yang dicanangkan oleh pemerintah. Ruang lingkup yang akan dibahas dalam tulisan ini adalah bagaimana gambaran persepsi masyarakat tentang Covid-19? Seperti apa wujud nyata keikutsertaan pemuka agama dalam membantu mensukseskan program vaksinasi massal dari pemerintah? Dengan menguraikan ini, ada tujuan dan manfaat dari tulisan ini. Kebermanfaatan dari tulisan ini menjadi panduan bagi pemuka agama yang berfungsi sebagai komunikator sekaligus mediator kepada umat dalam mengkampanyekan program vaksinasi.

\section{METODE}

Dalam menguraikan gagasan pada topik ini, artikel ini akan menerapkan metode kualitatif yang berorientasi pada studi literatur. Menurut Bogdan dan Biklen penelitian kualitatif merupakan prosedur penelitian yang menghasilkan tipe data deskriptif berupa ucapan atau tulisan dan perilaku orang-orang yang diamati di dalam suatu konteks dan yang dikaji dari sudut pandang yang lengkap dan komprehensif, maupun secara menyeluruh (Bogdan \& Biklen, 1997). Zaluchu mengemukakan pendekatan yang mengarah pada kualitatif bersifat relatif, hermeneutik dan interpretatif. Itu karena pendekatan kualitatif ini lebih 
banyak menggunakan analisis teori, dan hermeneutik yang kuat untuk sampai pada sebuah kesimpulan (Zaluchu, 2020b). Sumber data primer dalam tulisan ini diperoleh dari jurnal dan buku. Langkah-langkah yang dilakukan dengan cara membaca referensi berkaitan topik ini, kemudian mendeskripsikan, menguraikan dan kemudian menyatakan pandangan penulis serta menguraikan secara konferensif.

\section{HASIL DAN PEMBAHASAN}

\section{Gambaran Persepsi Masyarakat tentang Covid-19}

Pergolakan di media sosial tentang wacana vaksinasi massal yang akan dilakukan oleh pemerintah tidak serta-merta disambut secara positif oleh semua masyarakat. Langkah pemerintah untuk melakukan percepatan penanganan Covid-19 di Indonesia adalah dengan mengeluarkan wacana vaksinasi massal bagi semua warga Indonesia di masa mendatang. Sebelumnya, ketika pemerintah belum secara resmi merilis bagaimana prosedur pelaksanaan vaksinasi ini, wacana tersebut telah dinilai kontroversial sehingga mengundang banyak kalangan untuk memberikan pendapatnya di berbagai media (Rachman \& Pramana, 2020, p. 100).

Adanya sikap keberatan sebagian masyarakat menolak vaksin tentu didasari dari cara pandang mereka terhadap pandemi Covid-19 ini. Cara pandang tentang Covid-19 ini dipengaruhi oleh berbagai berita dan data faktual yang terjadi di lapangan. Berita dan data faktual itu membentuk pemahaman sebagian masyarakat hingga menyatakan bahwa wabah Covid19 adalah sebuah konspirasi yang tentunya berpotensi menimbulkan kerusakan dalam tatanan kehidupan bernegara dan bermasyarakat (Usman, Iskandar, \& Aswar, 2021).

Munculnya gerakan menolak untuk di vaksin tentu didasari dari beragamnya persepsi masyarakat pada Covid-19 itu sendiri. Perbedaan persepsi masyarakat tentang pandemi ini dapat dibingkai dalam tiga gambaran secara umum jika diamati dari media sosial maupun dari faktual. Kelompok pertama adalah orang-orang yang berpandangan bahwa Covid-19 ha- nyalah sebuah kebohongan, atau rekayasa yang diatur oleh para elit global. Kelompok pertama ini berpandangan bahwa Covid-19 didesain oleh elit global untuk menghancurkan perekonomian dunia, dan mendesain sistem dunia agar setiap manusia dapat dikontrol berdasarkan kehendak elit global. Itulah sebabnya kelompok pertama ini lebih cenderung berpandangan bahwa penyakit Covid-19 tidak real secara biologis dan ini cenderung bersifat konspirasi (Lubis, 2021). Menurut Uscinski et al. (2020) dalam penelitiannya, mereka yang berpandangan Covid-19 sebagai sebuah konspirasi didasarkan pada dua hal yaitu karena faktor psikologis dan faktor motivasi dari orang tersebut. Kedua faktor ini mempengaruhi kelompok pertama sehingga berimplikasi tidak memercayai pendapat sains dan medis, karena Covid-19 dianggap telah bercampur dengan urusan politik (Uscinski et al., 2020).

Faktor yang menyebabkan adanya orangorang yang memercayai Covid-19 sebuah konspirasi tidak lepas dari masifnya di dunia maya berita-berita hoax mengenai Covid-19. Laju berita hoax yang begitu deras menyebabkan sebagian masyarakat lebih meyakini Covid-19 bersifat konspirasi dibandingkan faktual. Arisanty dan Wiradharma (2020) mengemukakan penyebaran informasi hoax di media sosial masih sulit dikendalikan. Berbagai upaya telah dilakukan pemerintah untuk memberantas informasi hoax, bahkan Kementerian Kominfo RI sampai memilih keputusan untuk memblokir akun yang melakukan penyebaran hoax, terutama yang ada di dalam media sosial. Akan tetapi, tetap saja informasi hoax masih ada dan semakin meningkat penyebarannya (Arisanty \& Wiradharma, 2020). Pendapat senada dikemukakan Setiawan Kementerian Komunikasi dan Informatika mencatat hingga pertengahan April 2020 sampai sekarang berita hoax yang menyebar di tengah pandemi Covid-19. Hoaks tersebut tersebar di 1209 platform digital, seperti Facebook, Instagram, Twitter, dan YouTube (B. Setiawan, Pawito, \& Hastjarjo, 2020). Mereka yang lebih memercayai Covid-19 sebagai sebuah konspirasi adalah mereka yang getol-getol menolak wacana vaksinasi massal sebagai sebuah keharusan. 
Kelompok kedua adalah mereka yang mempercayai Covid-19 merupakan penyakit namun tidak sengeri dan semenakutkan sebagaimana yang digembar-gemborkan di media massa. Kelompok kedua ini berpandangan Covid-19 memang nyata, akan tetapi media massa dan lainnya menunggangi pandemi ini untuk mendapatkan keuntungan. Media massa (televisi) dalam penayangan berita Covid-19 sudah mengarah pada over-dosis. Publik menilai peliputan berita yang disiarkan oleh televisi terkait Covid-19 bukan lagi pada penyampaian informasi, namun sudah seperti menciptakan suasana yang horor bagi jiwa pemirsa. Tayangan televisi terkait Covid-19 yang dianggap sebagian masyarakat menakut-nakuti, hingga memunculkan keberatan para netizen dengan membuat tagar kampanye "matikan TV" sebagai bentuk protes mereka kepada media TV (Simon, 2020). Media televisi secara serentak membombardir siaran berita Covid-19 kepada masyarakat di seluruh tanah air tanpa hentinya dan selalu up to date dari pagi sampai malam dalam peliputannya mengenai Covid-19 (Simon, 2020). Cinelli (2020) menyebut penyebaran informasi seputar Covid-19 yang secara berulangulang dengan intensitas tinggi amat sangat mempengaruhi perilaku orang dan mengubah keefektifan tindakan penanggulangan yang dilakukan oleh pemerintah. Efek dari peliputan media tentang pandemi ini menimbulkan ketakutan dan histeris karena propaganda yang dibesar-besarkan oleh media. Melki menyebut framing yang dilakukan media dalam peliputan Covid-19 cenderung berfokus pada peristiwa-peristiwa utama, seperti kasus yang baru terdeteksi dan apa tindakan pemerintah. Framing yang dilakukan media dengan menampilkan berita-berita yang sensasional tentang Covid-19 dengan cakupan sub-stansial dari skenario terburuk apa yang akan terjadi. Akibatnya, media cenderung lebih kuat menimbulkan rasa takut dibandingkan mempromosikan pengetahuan berkaitan virus ini. Bila peliputan media lebih mengarah pada bingkai negatif mengenai pandemi ini, pembingkaian tersebut dapat mengarahkan dan mempengaruhi persepsi masyarakat terhadap informasi yang disampaikan (Melki et al., 2020).
Kelompok kedua ini juga meyakini pandemi Covid-19 adalah penyakit biasa sebagaimana penyakit pada umumnya, namun yang membuatnya menjadi menakutkan adalah karena pihak-pihak lain yang menunggangi status pandemi ini untuk mendulang keuntungan. Bentuk keuntungan yang diambil dengan cara mengkorupsi anggaran dana dari Menteri Kesehatan (Alfiyah, 2021). Ada juga rumah sakit dan oknum tenaga medis bertindak mencari keuntungan dengan "melabeli" orang yang sakit atau meninggal dengan status Covid-19. Pelabelan Covid-19 bagi pasien ini tentu bertujuan agar anggaran yang dijanjikan oleh pemerintah diterima (Simon \& Anderson, 2020). Dengan adanya jaminan insentif yang diberikan pemerintah kepada rumah-rumah sakit yang menjadi rujukan pemerintah untuk penanggulangan Covid19, sebagian di daerah-daerah didapati adanya rumah sakit yang nakal dengan sengaja meng-covid-kan pasien demi sebuah insentif. Mengeruk rupiah dengan melabeli korban meninggal karena Covid-19, sungguh perbuatan yang tak berkeperi-manusiaan. Dengan adanya peristiwa-peristiwa semacam ini, mengindikasikan bahwa rasa kemanusiaan perlahan luntur karena pengaruh Covid-19 (Simon \& Anderson, 2020, pp. 92-93). Dengan adanya fakta yang tersaji, kelompok kedua ini berpandangan tidak menolak vaksin namun juga tidak menunjukkan bahwa vaksin sebagai kebutuhan yang diperlukan di masa pandemi ini.

Golongan kelompok ketiga adalah masyarakat yang meyakini Covid-19 adalah peristiwa nyata, tanpa rakayasa dan terlebih tidak ditunggangi kepentingan politik apalagi ekonomi. Golongan ini tentunya amat menantikan vaksin hadir agar kehidupan normal segera tiba. Oleh sebab itu, vaksin dipercayai akan membawa kehidupan normal sesegera mungkin. Vaksin sangat penting untuk melawan infeksi virus khususnya yang menyerang pernapasan, oleh karena itu vaksin akan membentuk kekebalan tubuh melalui pembentukan antibodi (Arshadi et al., 2020). Calina et al. (2020) mengemukakan dalam konteks pandemi Covid-19, imunisasi penduduk global melalui vaksinasi merupakan prioritas kesehatan masyarakat saat ini. Tujuan dari vaksinasi massal ini untuk memberi- 
kan kekebalan tubuh. Dengan adanya vaksin ini akan memberikan dampak ekonomi yang besar bagi pencipta vaksin. Namun yang menjadi tantangan saat ini adalah bagaimana menjamin vaksin yang saat ini hadir teruji secara ilmiah dan keamanannya ketika dilakukan uji coba di laboratorium sebelum diproduksi secara massal (Calina et al., 2020, p. 3). Dengan adanya vaksinasi massal yang telah diwacanakan oleh pemerintah, kelompok ini tentu menantikan dan mengharapkan percepatan realisasi vaksinasi massal bagi masyarakat tanah air. Mereka yang mengharapkan percepatan realisasi vaksin terlaksana dalam memandang Covid-19, mendorong dan mengajak orang lain untuk merefleksikan hidupnya dalam kaitan agama agar manusia semakin menobatkan diri pada Sang Ilahi (Simon, Dully, Yulianto, \& Wibowo, 2021, p. 67).

\section{Keikutsertaan Pemuka Agama dalam Mensukseskan Program Vaksin}

\section{Mengedukasi Jemaat Melalui Mimbar}

Di Indonesia otoritas agama masih memainkan peran yang signifikan di tengah masyarakat yang religius, keotoritasan agama itu semakin terlihat secara aktif di situasi pandemi Covid-19 sekarang ini (Siregar \& Hsb, 2020). Fletcher (2004) mengemukakan agama adalah salah satu sumber utama yang digunakan untuk menghasilkan makna dalam hidup. Agama seseorang tidak hanya melibatkan seperangkat keyakinannya, tetapi juga keterlibatan dalam komunitas orang lain yang berpikiran sama (Fletcher, 2004). Kuatnya pengaruh agama mengatur tatanan masyarakat tanah air karena peran dari pemuka agama yang mengajarkan dan mengkhotbahkan isi kitab suci kepada jemaat. Peran pemuka agama yang signifikan dalam membentuk image bangsa Indonesia yang religius dapat dilihat dari kultur masyarakatnya. Ini menunjukkan pemuka agama mempunyai andil besar dalam melakukan hal itu. Borrong (2015) mengemukakan tugas seorang pendeta (rohaniawan) sebagai pemimpin rohani umat adalah memberikan pengajaran rohani dan moral, yang bertujuan membuat kehidupan jemaat bertambah baik secara psikis dan batiniah. Dari pengajaran yang dilakukan oleh pemuka agama itu, jemaat diharapkan dapat mematuhi sejumlah norma moral dan agama yang dianjurkan dalam Alkitab, sehingga hidup mereka benar-benar dipenuhi kedamaian dan kesejahteraan jasmani dan rohaninya. Karena itu pendeta bukan hanya fasih pada isi kitab suci, tetapi juga ia menjadi teladan dan contoh yang baik (Borrong, 2015, p. 81). Dengan pendeta menjadi teladan, maka jemaat dan lingkungan secara moral dipengaruhi kearah yang benar.

Situasi pandemi sekarang ini, keikutsertaan pemuka agama selain memotivasi umat agar tetap sabar dan bertahan di tengah kesukaran, pemuka agama juga dapat melibatkan dirinya dalam mengedukasi jemaat mengenai vaksin. Melibatkan diri untuk mengedukasi jemaat tentang vaksin menandakan pemuka agama menjadi komunikator pemerintah agar terselenggaranya program vaksinasi massal yang telah diwacanakan pemerintah. Aula (2020) mengemukakan pemuka agama perlu berperan mengatasi pandemi Covid-19. Peran ini memang harus dilakukan oleh berbagai pihak, termasuk kalangan tokoh agama. Tokoh agama yang memiliki figur karismatik, memiliki kekuatan khusus yang dapat memengaruhi tindakan masyarakat yang menjadi komunitas mereka. Pesan yang disampaikan oleh tokoh agama memiliki kecenderungan untuk diikuti, baik substansi pesannya atau pun buruk (Aula, 2020). Dari hal itu tokoh agama berpengaruh terhadap kepatuhan masyarakat dalam mengikuti apa yang dicanangkan oleh pemerintah bila tokoh agama ikut berperan serta.

Andil keterlibatan pemuka agama dalam membantu program vaksinasi yang dicanangkan oleh pemerintah adalah dengan mengedukasi jemaat secara langsung melalui mimbar. Mimbar adalah panggung kecil tempat berkhotbah yang biasa dipergunakan oleh pendeta ketika menyampaikan isi khotbahnya di gereja. Edukasi yang dilakukan oleh pemuka agama perihal vaksin kepada jemaat menunjukkan wujud keikutsertaan dan sinergitas kepada pemerintah sebagai komunikator dalam penataan moral dan penataan perilaku jemaat. Ini pula yang dilakukan oleh Church of God in Christ (COGIC) di AS, mereka 
membentuk gugus tugas Covid-19 yang terdiri dari para dokter, pengacara, cendekiawan, pendeta, dan uskup, dalam membendung penyebaran cepat epidemi penyakit corona virus yang saat ini berdampak pada dunia (Daniels, 2021). Dengan mengedukasi jemaat melalui mimbar, para pemuka agama bertanggungjawab terhadap kredibilitas kefaktualan informasi yang disampaikan. Hal itu dapat dilakukan dengan rajin belajar dari sumber referensi yang terpercaya sehingga mengetahui informasi yang tepat yang dapat digunakan dalam mengedukasi jemaat yang digembalakan. Edukasi yang dilakukan pemuka agama melalui mimbar kepada jemaat, itu bagian dari tanggung jawab sebagai warga Negara untuk menaati pemerintah sebagai wakil Allah di bumi ini (Rm. 13:1-7). Yasinta dan Chandra (2021, p. 90) mengemukakan gereja maupun orang percaya hendaknya terlibat dengan ikut mendukung dan berpartisipasi dalam kebijakan pemerintah dan menghidupi Injil dalam kehidupan berbangsa dan bernegara, baik di dalam ranah publik, sosial maupun di dalam ranah politik.

Fungsi mimbar tidak hanya seputar pemberitaan firman Allah, namun mimbar dapat difungsikan untuk pengajaran firman secara spesifik tentang masalah-masalah sosial. Yesus pun melakukan hal ini, ketika Ia berada di Bait Suci (tempat sembahyang agama Yahudi), Ia menggunakan sarana itu untuk menyampaikan masalah masalah sosial yang terjadi di masa itu (Mat. 12:914; Mrk. 6:1-5; Luk. 4:18-19). Eyo (2019) mengemukakan Injil Sinoptik memberikan gambaran bagaimana kuatnya kepedulian sosial yang ada dalam diri Yesus. Ini dibuktikan dari peristiwa Ia memberikan makan lima ribu orang (Yoh. 6:114) dan 4 ribu orang (Mat. 14:14-21). Peristiwa Yesus memberikan makan ribuan orang memperlihatkan kuatnya belaskasihan, kemurahan hati dan perhatian Yesus kepada orang yang mengikuti-Nya. Ia memberikan mereka makan, agar tidak mengalami kelelahan dan kelaparan pada waktu mereka mengikuti-Nya. Jiwa sosial Yesus melalui belas kasihan, kemurahan hati dan kebaikan-Nya merupakan lambang etika kebajikan (Eyo, 2019, p. 23). Melalui edukasi yang dilakukan oleh pendeta di mimbar sudah turut berparti- sipasi dalam menyukseskan vaksinasi kepada masyarakat. Tokoh agama mampu memberikan perubahan besar terhadap kondisi sosial masyarakat atau jemaat. Mereka mampu menggeser tindakan masyarakat kearah tindakan yang mereka kehendaki. Faktor itu dapat tercipta karena tokoh agama memiliki kemampuan dalam menjelaskan persoalan-persoalan yang rumit bagi masyarakat menjadi lebih mudah (Aula, 2020).

\section{Memberi Contoh Dengan Ikut Divaksin}

Munculnya keraguan terhadap vaksin bagi sebagian orang didasari alasan apakah halal serta apakah vaksin aman ketika disuntikkan ditubuh. Keraguan dan kekuatiran akan vaksin disuarakan oleh lembaga maupun individu agar terlebih dahulu pemerintah membuktikan bahwa vaksin itu aman tanpa menimbulkan efek samping berbahaya bagi tubuh (Rachman \& Pramana, 2020). Bukan hanya di situasi pandemi ini ada yang meragukan vaksin Covid-19, namun vaksin imunisasi dan sejenisnya pun ada sebagian orang meragukannya. Ini pula yang diteliti oleh Gust et al. (2008) dalam tulisannya mengapa orang tua di Amerika terjadi peningkatan keraguan anaknya di vaksin imunisasi? Alasan pertama, para orang tua ini tidak meyakini vaksin imunisasi itu yang terbaik bagi tubuh anaknya. Alasan kedua, karena adanya efek samping yang ditimbulkan oleh vaksin imunisasi. Alasan ketiga, para orang tua ini tidak mendapatkan jawaban secara detail atau pemahaman mumpuni dari para tenaga kesehatan mengenai vaksin. Alasan keempat, kurang terampilnya komunikasi tenaga kesehatan dalam mengkomunikasi dan menjelaskan kepada mereka mengenai vaksin imunisasi (Gust et al., 2008).

Dengan pemerintah memberi contoh telah divaksin, pemuka agama diharapkan andil terlibat ikut divasin sebagai bentuk dari keikutsertaan merealisasikan program pemerintah dalam vaksinasi massal. Keterlibatan pemuka agama dengan ikut divaksin sekaligus memerangi dan memudarkan stigma vaksin tidak aman. Selain itu keikutsertaan pemuka agama di vaksin agar antusiasme masyarakat meningkat, me- 
ngingat kerelaan masyarakat menerima vaksin belum sepenuhnya bersedia (Ichsan, Hafid, Ramadhan, \& Taqwin, 2021). Keikutsertaan pemuka agama divaksin itu bagian dari mengedukasi jemaat serta meningkatkan antusiasme umat agar bersedia dalam vaksinasi massal yang akan diselenggarakan negara.

Nicolas (2021) mengemukakan bersedia di vaksin Covid-19 tanda ketaatan kepada pemerintah sebagai wakil Allah di bumi, sekaligus menunjukkan tindakan kasih untuk menjaga diri dan orang lain di sekitar. Apabila menolak vaksin dengan alasan doktrinal Kitab Suci, itu merupakan kekeliruan yang tidak berdasar (Nicolas, 2021). Ikut terlibat untuk di vaksin menunjukkan contoh kepada jemaat sekaligus memberikan apresiasi kepada tenaga medis dan saintik yang bekerja keras dalam menciptakan vaksin Covid-19. Oleh Haynes (2020) mengemukakan jika vaksin telah melalui tahap uji ketiga apalagi bila diuji cobakan kepada tiga puluh ribu orang lebih, maka secara klinisnya vaksin itu dapat dikatakan aman dan manjur. Vaksin yang sudah dinyatakan aman karena melalui uji coba, dapat ditindaklanjuti dengan mendistribusikan kepada semua orang (Haynes et al., 2020). Vaksin akan beresiko kecil apabila vaksin itu telah melalui tahap uji dan prosedural keilmiahan.

\section{Aktif Terlibat Dalam Mengcounter Berita Hoax}

Pada saat berita Covid-19 dinyatakan oleh WHO sebagai pandemi global, saat itu juga terjadi kepanikan massal dihampir setiap negara. Efek dari kepanikan dan ketakutan masyarakat global mengenai Covid-19, menyebabkan mahalnya harga masker, hand sanitizer dan baju APD (alat pelindung diri) yang digunakan oleh tenaga medis serta mulai kacaunya ekonomi global (Soleh, 2020). Pada waktu yang bersamaan juga bertebaran berita Covid-19 baik hoax yang sifatnya mengarah pada konspirasi. Malahan hoax yang bersifat teologis bertebaran dalam lingkup kekristenan sendiri. Yang dimaksud hoax yang bersifat teologis bila dikaitkan pada Covid-19 sebagai representasi dari tanda Anti-Kris dalam bilangan 666 sebagaimana yang tertulis dalam Wahyu 13:18 (Christina, 2020). Imbas dari munculnya pemahaman yang mengaitkan Covid-19 bagian dari bilangan 666 menyebabkan menolak vaksinasi dengan alasan yang mengkaitkannya dengan microchip 666 (Nicolas, 2021). Nyatanya angka bilangan 666 tidak berkaitan dengan Anti-kris maupun microchip. Setiawan melakukan penelitian terkait teks Wahyu 13 mengenai bilangan 666 itu. Di dalam temuannya, bilangan 666 melambangkan usaha manusia yang berusaha menyamai Allah untuk mencapai kuasa yang tidak terbatas, namun mereka gagal dalam menyamai Allah (R. Setiawan, 2018, p. 20).

Massifnya berita hoax mengenai Covid-19 baik yang bersifat medis maupun teologis, turut memprihatinkan karena berimbas pada penolakan vaksin. Direktur WHO mengemukakan akibat dari berita Covid-19 yang bersifat anonim ini, menyebabkan kebingungan bagi penduduk global. WHO pun menghimbau agar para CEO selaku pembuat platform media sosial dan pemimpin negara untuk bertindak cepat dalam meng-counter laju penyebaran berita bohong di berbagai platform media (Cucinotta \& Vanelli, 2020). Oleh Kadam dan Atre (2020) mengemukakan berita ketakutan dan kepanikan massal mengenai Covid-19 di India lebih cepat penyebarannya dibandingkan dengan penyebaran virus ini. Kondisi yang buruk ini tentu juga dipengaruhi oleh berita yang seolah kredibel namun palsu (Kadam \& Atre, 2020).

Penyebaran berita Covid-19 di media sosial antara yang faktual dan bersifat hoax, sama-sama mewarnai jagat media sosial (Naeem, Bhatti, \& Khan, 2021). Dengan kondisi seperti ini, keikutsertaan pemuka agama dalam membantu program pemerintah untuk mewujudkan wacana vaksinasi bagi semua masyarakat dengan aktif terlibat dalam mengcouner beritaberita hoax di media sosial. Bentuk counter keikutsertaan pemuka agama pertama, dengan berkewajiban membantu, serta turut hadir dengan memberikan data atau informasi terkait penanganan pandemi secara akurat dan terpercaya kepada jemaat (Muchammadun et al., 2021). Kedua, memerangi berita palsu atau bersifat anonim seputar vaksin dapat dilakukan dengan cara rajin men-share berita-berita faktual baik di grup Whatsapp, maupun di berbagai jejaring media sosial. 
Tujuan pemuka agama melakukan hal ini, agar menciptakan dan membantu dominasi berita non-hoax atau non-konspirasi beredar di line media sosial (Simon, 2020).

Ketiga, pemuka agama terlibat aktif melawan arus berita yang bersifat palsu seputar vaksin di media sosial karena media sosial saat ini bukan lagi sebatas sarana mencari teman, tetapi secara perlahan konten (berita) di media sosial dijadikan rujukan faktual. Bahkan di masa kini, media sosial sudah menjadi kebutuhan primer bagi siapa saja, karena media sosial dapat mempermudah semua aktivitas atau kegiatan seseorang baik yang bersifat sosial, ekonomi, terlebih keagamaan (Simon, Lie, \& Komaling, 2021, p. 57). Ketidak-tahuan dalam pemanfaatan media sosial secara bijaksana menjadi salah satu penyebab yang mendorong semakin menjamurnya budaya hoax di tengah masyarakat Indonesia. Terlebih jika dikaitkan dengan faktor otonomi user yang bebas mengakses internet untuk kepentingan dan keperluan apapun, mendorong orang dengan mudah mengunggah berbagai konten (tulisan, gambar dan video) yang kemudian menyebar cepat di dunia maya (Zaluchu, 2020a). Keikutsertaan pemuka agama dalam mengcounter berita yang bersifat ambigu tentang vaksin, sekaligus mencegah jemaat untuk tidak berperilaku liar karena pengaruh berita hoax atau rekayasa.

\section{KESIMPULAN}

Pandemi Covid-19 yang melanda hampir semua negara menyebabkan setiap orang seakan mengalami kesulitan hidup di berbagai sisi. Kesulitan itu tampak akan berakhir dengan hadirnya vaksin yang sudah mulai tersedia di setiap negara tak terkecuali Indonesia. Dengan tersedianya vaksin, ternyata tidak semua masyarakat menyambut dengan antusias peri-

\section{DAFTAR RUJUKAN}

Alfano, V., \& Ercolano, S. (2020). The efficacy of lockdown against COVID-19: A crosscountry panel analysis. Applied Health Economics and Health Policy, 18, 509-517. hal ini. Ini didasarkan pada pandangan masyarakat tentang Covid-19. Ada sebagian orang yang menilai bahwa Covid-19 bersifat hoax atau rekayasa, sementara sebagian lagi memandang Covid-19 tidak sengeri dan semenakutkan sebagaimana yang digembar-gemborkan oleh media. Namun, ada juga yang menilai Covid-19 real tanpa rekayasa dan tanpa ditunggangi apapun sehingga vaksinasi massal sebagai kebutuhan utama yang sudah semestinya dilakukan pemerintah dalam menormalkan kembali semua kegiatan.

Vaksinasi massal akan semakin cepat terwujud bila keikutsertaan pemuka agama terlibat untuk mendukung program pemerintah dalam melaksanakan vaksinasi massal, karena pemuka agama memiliki karisma yang dapat memengaruhi kehidupan jemaat secara spiritual maupun sosial. Wujud kongkrit dari keikutsertaan pemuka agama untuk membantu mensukseskan program vaksinasi dengan mengedukasi jemaat tentang vaksin dari mimbar, memberi contoh dengan turut serta di vaksindan ikut memerangi berita yang bersifat hoax, atau ambigu di media sosial.

Sebagai saran dari tulisan ini, pemerintah perlu mempertimbangkan pemberian jaminan insentif bagi masyarakat yang telah menerima vaksin. Memberikan insentif atau jaminan asuransi kesehatan secara gratis andai vaksin menimbulkan efek samping bagi tubuh sipenerima. Dengan adanya insentif atau jaminan yang dituangkan pemerintah dalam aturan Perpres atau Perda, itu mampu mengikis suara-suara yang menolak vaksin. Pemberian insentif atau jaminan perlindungan bagi penerima vaksin, sekaligus juga mempercepat harapan pemerintah dalam merealisasikan vaksinasi massal ke seluruh masyarakat tanah air. Kolaborasi yang tercipta antara pemerintah dan pemuka agama akan membantu program merealisasikan vaksinasi massal segera terwujud.

Alfiyah, N. (2021). Pertanggungjawaban Pidana Pelaku Korupsi Bantuan Sosial Di Masa Kedaruratan Pandemi Covid-19. Jurnal Education and Development, 9(2), 378-382. https://doi.org/10.37081/ed.v9i2.2539 
Arisanty, M., \& Wiradharma, G. (2020). The Acceptance and Resharing Behavior of Hoax Information on Social Media. Jurnal Studi Sosial Dan Politik, 4(2), 87-99. https://doi.org/10.19109/jssp.v4i2.6609

Arshadi, A. K., Webb, J., Salem, M., Cruz, E., CaladThomson, S., Ghadirian, N., ... Yuan, J. S. (2020). Artificial Intelligence for COVID-19 Drug Discovery and Vaccine Development. Frontiers in Artificial Intelligence, 3, 65. https://doi.org/10.3389/frai.2020.00065

Aula, S. K. N. (2020). Peran Tokoh Agama Dalam Memutus Rantai Pandemi Covid-19 Di Media Online Indonesia. Living Islam: Journal of Islamic Discourses, 3(1), 125. https://doi.org/10.14421/lijid.v3i1.2224

Bogdan, R., \& Biklen, S. K. (1997). Qualitative research for education. Allyn \& Bacon Boston, MA.

Borrong, R. P. (2015). Signifikansi kode etik pendeta. Gema Teologi, 39(1).

Calina, D., Docea, A., Petrakis, D., Egorov, A., Ishmukhametov, A., Gabibov, A., ... Tsatsakis, A. (2020). Towards effective COVID-19 vaccines: Updates, perspectives and challenges (Review). International Journal of Molecular Medicine, 46(1), 3-16. https://doi.org/10.3892/ijmm.2020.4596

Christina, E. (2020). Pandemi Covid-19 Adalah 666 ? Logia: Jurnal Teologi Pentakosta, 1(2), 122.

Cinelli, M., Quattrociocchi, W., Galeazzi, A., Valensise, C. M., Brugnoli, E., Schmidt, A. L., ... Scala, A. (2020). The COVID-19 social media infodemic. Scientific Reports, 10(1), 16598 https://doi.org/10.1038/s41598-020-73510-5

Cucinotta, D., \& Vanelli, M. (2020). WHO declares COVID-19 a pandemic. Acta Bio Medica: Atenei Parmensis, 91(1), 157-160. https://doi.org/10.23750/abm.v91i1.9397
Daniels, D. (2021). COVID-19, Science, and Race: A Black Pentecostal Engagement. Spiritus: ORU Journal of Theology, 6(1), 141-155.

Dwipayana, I. D. A. P. (2020). Efforts in Securing Vaccine for Covid-19 Outbreak in Indonesia. Health Notions, 4(10), 313-317. https://doi.org/10.33846/hn41001

Eyo, E. B. (2019). Jesus Christ The Philosopher: An Exposế. International Journal of Philosophy and Theology, 7(2). https://doi.org/10.15640/ijpt.v7n2a2

Fletcher, S. K. (2004). Religion and life meaning: Differentiating between religious beliefs and religious community in constructing life meaning. Journal of Aging Studies, 18(2), 171-185.

https://doi.org/10.1016/j.jaging.2004.01.005

Graham, B. S. (2020). Rapid COVID-19 vaccine development. Science, 368(6494), 945-946. https://doi.org/10.1126/science.abb8923

Gust, D. A., Darling, N., Kennedy, A., \& Schwartz, B. (2008). Parents With Doubts About Vaccines: Which Vaccines and Reasons Why. Pediatrics, 122(4), 718-725. https://doi.org/10.1542/peds.2007-0538

Haynes, B. F., Corey, L., Fernandes, P., Gilbert, P. B., Hotez, P. J., Rao, S., ... Arvin, A. (2020). Prospects for a safe COVID-19 vaccine. Science Translational Medicine, 12(568), 112. https://doi.org/10.1126/scitranslmed.abe094 8

Ichsan, D. S., Hafid, F., Ramadhan, K., \& Taqwin, T. (2021). Determinan Kesediaan Masyarakat menerima Vaksinasi Covid-19 di Sulawesi Tengah. Poltekita: Jurnal Ilmu Kesehatan, 15(1), 1-11. https://doi.org/10.33860/jik.v15i1.430

Imhoff, R., \& Lamberty, P. (2020). A Bioweapon or a Hoax? The Link Between Distinct Conspiracy Beliefs About the Coronavirus Disease (COVID-19) Outbreak and Pandemic Behavior. Social Psychological 
and Personality Science, 11(8), 1110-1118. https://doi.org/10.1177/1948550620934692

Isriawaty, F. S., \& others. (2015). Tanggung Jawab Negara Dalam Pemenuhan Hak Atas Kesehatan Masyarakat Berdasarkan Undang Undang Dasar Negara Republik Indonesia Tahun 1945. Tadulako University.

Jeannifer, J. (2021). Sanksi Pidana Terhadap Penolak Vaksin Covid-19 Di Indonesia. Al Qodiri: Jurnal Pendidikan, Sosial Dan Keagamaan, 19(1), 164-169.

Kadam, A. B., \& Atre, S. R. (2020). Negative impact of social media panic during the COVID-19 outbreak in India. Journal of Travel Medicine, 27(3), taaa057. https://doi.org/10.1093/jtm/taaa057

Lubis, N. (2021). Agama Dan Media: Teori Konspirasi Covid-19. Jurnal Kajian Islam Interdisipliner, $\quad 4(1)$, $45-58$ https://doi.org/10.14421/jkii.v4i1.1188

Makmun, A., \& Hazhiyah, S. F. (2020). Tinjauan Terkait Pengembangan Vaksin Covid 19. Molucca Medica, 13(2), 52-59. https://doi.org/10.30598/molmed.2020.v13.i 2.52

Masnun, M. A., Sulistyowati, E., \& Ronaboyd, I. (2021). Pelindungan Hukum Atas Vaksin Covid-19 Dan Tanggung Jawab Negara Pemenuhan Vaksin Dalam Mewujudukan Negara Kesejahteraan. DiH: Jurnal Ilmu Hukum, 17(1), 35-47. https://doi.org/10.30996/dih.v17i1.4325

Melki, J., Tamim, H., Hadid, D., Farhat, S., Makki, M., Ghandour, L., \& Hitti, E. (2020). Media Exposure and Health Behavior during Pandemics: The Mediating Effect of Perceived Knowledge and Fear on Compliance with COVID-19 Prevention Measures. Health Communication, 1-11. https://doi.org/10.1080/10410236.2020.1858 564

Meri, Khusnul, Suhartati, R., Mardiana, U., \& Nurpalah, R. (2020). Pemberdayaan
Masyarakat Dalam Penggunaan Hand Sanitizier dan Masker Sebagai Upaya Preventif Terhadap Covid-19. Bantenese Jurnal Pengabdian Masyarakat, 2(1), 26-33. https://doi.org/10.30656/ps2pm.v2i1.2340

Muchammadun, M., Rachmad, S. H., Handiyatmo, D., Tantriana, A., Rumanitha, E., \& Amrulloh, Z. (2021). Peran Tokoh Agama dalam Menangani Penyebaran Covid-19. Religious: Jurnal Studi Agama-Agama Dan Lintas Budaya, 5(1), 87-96. https://doi.org/10.15575/rjsalb.v5i1.10378

Naeem, S. Bin, Bhatti, R., \& Khan, A. (2021). An exploration of how fake news is taking over social media and putting public health at risk. Health Information \& Libraries Journal, $38(2)$, 143-149. https://doi.org/10.1111/hir.12320

Nicolas, D. G. (2021). Analisis Kontroversi Vaksin Covid-19, Microchip 666 dan Antikris Di Tengah Gereja Di Indonesia Berdasarkan Wahyu 13: 16-18. Syntax Literate; Jurnal Ilmiah Indonesia, 6(2), 687-694. https://doi.org/10.36418/syntaxliterate.v6i2.2181

Pramana, C., Susanti, R., Ernawati, K., Darmawan, I. P. A., Miftah, M. Z., Lestyowati, J., ... Ramadhani, R. (2021). Distance Learning In Primary Schools During The Covid-19 Pandemic In Indonesia: Challenges, Solutions, And Projections. Turkish Journal of Computer and Mathematics Education (TURCOMAT), 12(4), 263-270. https://doi.org/10.17762/turcomat.v12i4.502

Rachman, F. F., \& Pramana, S. (2020). Analisis Sentimen Pro dan Kontra Masyarakat Indonesia tentang Vaksin COVID-19 pada Media Sosial Twitter. Indonesian of Health Information Management Journal (INOHIM), $\quad 8(2), \quad$ 100-109. https://doi.org/10.47007/inohim.v8i2.223

Sari, A. P. (2021). Masih Banyak Warga Tolak Vaksin Covid-19, DPR Minta Pemda 
Gencarkan Sosialisasi. Retrieved from Kompas.com website: https://nasional.kompas.com/read/2021/03/2 5/16325281/masih-banyak-warga-tolakvaksin-covid-19-dpr-minta-pemdagencarkan?page $=$ all

Satu, B. (2020). Sejumlah Alasan Warga Menolak untuk Disuntik Vaksin. In Berita Satu.

Setiawan, B., Pawito, P., \& Hastjarjo, S. (2020). Hoax amidst The Covid-19 Pandemic. The Proceedings of the 4th International Conference of Social Science and Education, ICSSED 2020, August 4-5 2020, Yogyakarta, Indonesia.

EAI.

https://doi.org/10.4108/eai.4-8-

2020.2302399

Setiawan, R. (2018). Tinjauan Terhadap Bilangan 666 Dalam Wahyu 13. Evangelikal: Jurnal Teologi Injili Dan Pembinaan Warga Jemaat,

2(1).

https://doi.org/10.46445/ejti.v2i1.89

Shahsavari, S., Holur, P., Tangherlini, T. R., \& Roychowdhury, V. (2020). Conspiracy in the time of corona: Automatic detection of covid-19 conspiracy theories in social media and the news. ArXiv Preprint ArXiv:2004.13783.

Simon, S. (2020). Respon Orang Kristen Terhadap Pemberitaan Televisi Mengenai Covid-19. Jurnal Gamaliel: Teologi Praktika, 2(2), 114-131.

https://doi.org/10.38052/gamaliel.v2i2.52

Simon, S., \& Anderson, L. (2020). Covid-19 Memudarkan Rasa Kemanusiaan Terhadap Sesama Dan Implikasinya Bagi Orang Percaya. Sabda: Jurnal Teologi Kristen, 1(2), 85-104.

Simon, S., Dully, S., Yulianto, T., \& Wibowo, A. P. (2021). Pandemi Covid-19 Dalam Perspektif Teologi Pentakosta. Ritornera - Jurnal Teologi Pentakosta Indonesia, 1(1).
Simon, S., Lie, T. L., \& Komaling, H. W. (2021). Prinsip-Prinsip Etika Kristiani Bermedia Sosial. DANUM PAMBELUM: Jurnal Teologi Dan Musik Gereja, 1(1), 56-68.

Siregar, P., \& Hsb, M. O. (2020). Peran Otoritas Agama di Masa Pandemi Covid 19. Akademika: Jurnal Keagamaan Dan Pendidikan, 16(2), 128-138.

Soleh, M. F. (2020). Penimbunan Alat Pelindung Diri pada Masa Pandemi Covid-19: Kajian Hukum Pidana Bidang Perlindungan Konsumen. Undang: Jurnal Hukum, 3(1), 131. https://doi.org/10.22437/ujh.3.1.1-31

Uscinski, J. E., Enders, A. M., Klofstad, C., Seelig, M., Funchion, J., Everett, C., ... Murthi, M. (2020). Why do people believe COVID-19 conspiracy theories? Harvard Kennedy School Misinformation Review, 1(3), 1-12. https://doi.org/10.37016/mr-2020-015

Usman, M. H., Iskandar, A., \& Aswar, A. (2021). COVID-19: Menguji Kebenaran Konspirasi Global. Jurnal Studi Agama Dan Masyarakat, 16(2), 122-131. https://doi.org/10.23971/jsam.v16i2.2238

Yasinta, P., \& Chandra, W. W. (2021). Kasih dan Takut Akan Allah Sebagai Dua Pilar Sikap Patuh Kepada Pemerintah: Sebuah Tinjauan Gramatika-Historis Roma 13: 1-7. CONSILIUM: Jurnal Teologi Dan Pelayanan, 22, 72-93.

Zaluchu, S. E. (2020a). Dinamika Hoax, Post-Truth dan Response Reader Criticism di Dalam Rekonstruksi Kehidupan Beragama. Religió: Jurnal Studi Agama-Agama, 10(1), 98-117. https://doi.org/10.15642/religio.v10i1.1310

Zaluchu, S. E. (2020b). Strategi Penelitian Kualitatif dan Kuantitatif Di Dalam Penelitian Agama. Evangelikal: Jurnal Teologi Injili Dan Pembinaan Warga Jemaat, 4(1), 28-38. https://doi.org/10.46445/ejti.v4i1.167 